\title{
Proti historické amnézii: čeští exiloví skladatelé Jan Novák a Antonín Tučapský versus oficiální kulturní politika
}

\section{Against Historical Amnesia: Czech Exile Composers Jan Novák and Antonín Tučapský versus Official Cultural Policy}

Martin Flašar / flasar@phil.muni.cz

Pavlína Němcová / 413487@mail.muni.cz

Department of Musicology, Faculty of Arts, Masaryk University, Brno, CZ

\begin{abstract}
One of the important research topics of Czech musicology is the issue of the clash of free-thinking composers with the ideologically distorted cultural policy of the Czechoslovak communist regime (1948-1989). Czech composers in exile were destined to be erased from the collective historical memory. Reconstruction of their work, life and significance in the context of contemporaries is therefore one of the basic tasks of caring for the heritage of musical culture.

Seen from Czechoslovakia, composers in exile could be perceived by their colleagues as cowards, or their foreign career could become a subject of envy. Seen from the other side, the external view of the politically deformed Czech music culture is very valuable for the objective reconstruction of the local situation. The study of exile music culture often tells far more about our own history than about the fates of exile composers.
\end{abstract}

\section{Key words}

Igor Stravinsky, Bohuslav Martinů, Jan Novák, Antonín Tučapský, Zdeněk Zouhar, exile composers, cultural policy, 20th century music, Union of Czechoslovak Composers 


\section{Úvod}

Jedním z důležitých výzkumných témat české muzikologie je problematika střetu svobodně smýšlejících skladatelů s ideologicky deformovanou kulturní politikou československého komunistického režimu (1948-1989). Čeští skladatelé v exilu byli obvykle předurčeni k vymazání z kolektivní historické paměti. Rekonstrukce jejich díla, života a významu v kontextu současníků je proto jedním ze základních úkolů péče o dědictví hudební kultury.

Při pohledu z Československa mohli být skladatelé v exilu vnímáni jejich kolegy jako zbabělci, případně se jejich zahraniční kariéra mohla stát přímo předmětem závisti. Naopak jejich pohled zvenčí na domácí politicky deformovanou hudební kulturu je naopak velmi cenný pro rekonstrukci lokální situace. Studium exilové hudební kultury totiž vypovídá často více o naší vlastní historii než o osudech exilových skladatelů.

\section{Bohuslav Martinů a aritmetika odcizení}

Jeden z nejslavnějších českých emigrantů 20. století, Milan Kundera, se ve svých spisech opakovaně vrací k otázce emigrace. Ve svém pozoruhodném eseji Improvisation en hommage à Stravinski vydané nakladatelstvím Gallimard jako součást Les testaments trahis Kundera analyzuje to, co nazývá „aritmetikou emigrace“. ${ }^{1}$ Je velmi pravděpodobné, že zde parafrázuje Stravinského prohlášení o svém Králi Oidipovi coby zkoumání „geometrie tragédie“. Kundera hovoří o schizofrenii umělce, který je rozpolcený mezi svou bývalou vlast a novou exilovou zemi. Klíčovým slovem emigrace je odcizení. Nově příchozí zpočátku poznává exilovou zemi jako cizinec. Postupně si zvyká na místní podmínky a během tohoto procesu přichází o svou bývalou zemi. Její postupné odcizování se stává zdrojem jeho vnitřního utrpení.

Emigraci lze chápat jako proces úniku ze, respektive do specifických podmínek. Tyto podmínky mají nejčastěji politickou, náboženskou nebo ekonomickou povahu. Je známo, že v české hudební historii 18. století existuje celé období nepřesně nazývané „hudební emigrací“. Tento fenomén čítá několik desítek hudebníků, kteří se rozhodli vydělávat si na živobytí v zahraničí. Nicméně mnohé z nich nebyly vủbec cizí, ve skutečnosti byli součástí celku habsburské monarchie, proto se v pravém slova smyslu o hudební emigraci nejednalo. ${ }^{2}$

Druhá nejsilnější vlna emigrace přišla ve 20. století. Čeští hudebníci měli několik př́ležitostí k opuštění své vlasti. Mezi nejdůležitější patřilo období druhé světové války

1 KUNDERA, Milan. Les testaments trahis. Paris: Gallimard, 1993. Kap. L'arithmétique de l'émigration, s. 112nn. Český překlad: Host 2006, č. 3, s. 22.

2 Podrobně k tomu viz např. FRANKOVÁ, Jana. Mýtus české hudební emigrace z pohledu Dlabačova slovníku. Musicologica Brunensia. 2015, roč. 50, č. 1, s. [73]-85. 
kvůli nacistické okupaci a po roce 1968 v souvislosti s okupací Československa vojsky Varšavského paktu a následnou tzv. normalizací.

Někteří z českých hudebníků již v průběhu těchto politických událostí v zahraničí pobývali, např́klad skladatel Bohuslav Martinů (1890-1959), který se nestal emigrantem z vlastního rozhodnutí, ale z důvodu radikální politické změny v jeho vlasti. Modelovým indikátorem těchto politických zvratů byla kantáta Polni mše zkomponovaná Bohuslavem Martinů k oslavě českých vojáků ve druhé světové válce. Český hudební kritik Antonín Sychra ji označil za vynikající dílo, které není exkluzivní ani experimentální a má proto všechny předpoklady $\mathrm{k}$ tomu, aby zlidovělo. $\mathrm{O}$ čtyři roky později po komunistickém převratu napsal, že Polni mše byla svou podivnou instrumentací vypočítána pro západní buržoazní publikum, nevyjadřuje bojové nadšení a optimismus lidu, jen pouhý stesk po domově. ${ }^{3}$ Jedno dílo, jeden recenzent, dva protichůdné názory. Oficiální česká hudební kultura se Bohuslavu Martinů odcizila.

\section{Jan Novák - muž určený $k$ historické likvidaci}

Jan Novák (1921-1984) byl moravský skladatel, mimo jiné žák Pavla Bořkovce v Praze, Aarona Coplanda a Bohuslava Martinů v USA. Po návratu v roce 1948 se stal úspěšným českým skladatelem koncertní, scénické a filmové hudby. Velkým propagátorem jeho díla byl např. Rafael Kubelík coby šéfdirigent Bavorského rozhlasového orchestru.

Český komunistický režim v padesátých letech minulého století použival zkratku „MUKL“ popisující „muže určeného k likvidaci“. V přeneseném smyslu bychom mohli historickou stopu Jana Nováka považovat za určenou k likvidaci. Novák byl obětí dlouhodobého nátlaku ze strany Svazu československých skladatelů, který jej v 50. letech nutil do spolupráce na realizaci programu socialistického realismu, což vytrvale odmítal. Po jeho odchodu v roce 1968 do Dánska, Itálie a později Německa byl odsouzen v nepř́tomnosti a alespoň jeho hudební dědictví bylo určeno $\mathrm{k}$ nucenému zapomnění. Jen několik jeho přátel si s ním v tomto těžkém období dopisovalo a snažilo se udržovat kontakt. Tato situace přetrvávala více než 20 let až do roku 1989. Na druhé straně „železné opony“ se jeho dílo prosazovalo jen pomalu. Štastný okamžik pro dílo Jana Nováka nastal v roce 1986 (dva roky po úmrtí skladatele), kdy Newyorská filharmonie uvedla jeho kantátu Dido v celovečerním programu společně s violoncellovým koncertem Antonína Dvořáka a Památnikem lidicim Bohuslava Martinů. Jan Novák následoval osudy svých vzorů, Igora Stravinského a Bohuslava Martinů. Stal se exilovým hudebním skladatelem, který dožil a byl pochován v zahraničí.

3 SYCHRA, Antonín. Bohuslav Martinů: Polní mše. Rytmus 11/1947-48, s. 123; MIHULE, Jaroslav. Martinů: Osud skladatele. Praha: Nakladatelství Karolinum, 2002, s. 432. 


\section{Rekonstrukce kulturního dědictví - z korespondence Antonína Tučapského}

Podobným procesem odcizení v exilové zemi si prošel také další moravský skladatel Antonín Tučapský (1928-2014), jehož jméno není v naší zemi příliš rozšířené, na rozdíl od exilové Velké Británie. Tam se proslavil především sborovou tvorbou, která se záhy rozšírila i do USA.

Podrobný průběžný popis procesu přerodu tuzemského skladatele ve skladatele s exilovou nálepkou předurčující jeho vymazání z naší národní historie můžeme nalézt v korespondenci se Zdeňkem Zouharem, Tučapského přítelem a kolegou ze studií oboru hudební a výtvarné výchovy na Pedagogické fakultě Masarykovy univerzity.

Jako v každém soukromém rozhovoru nalezneme i v této korespondenci osobní záležitosti týkající se každodenního života. Nicméně jsou to právě tyto informace, které ve své opravdovosti ukazují život dvou mladých skladatelů v Československu a následné srovnání se životem v „Západním světě“ díky emigraci Tučapského do Anglie. Nejedná se o žádná skandální odhalení diskrétní povahy, ale spíše o obraz politicko-umělecké scény a principů kariérních postupů. Lze si tedy udělat představu, jak bylo pro absolventa pedagogické školy obtížné se v totalitním režimu vůbec uchytit na nějaké nízké pozici, jaké další břímě to s sebou neslo, a jak bylo často lepší si vzápětí po získání nové práce začít hledat zaměstnání nové. Nehledě na - pro dnešní generace absolventů - téměř neuvěřitelný až úsměvný fakt, že ani umělcům nebyla udělena výjimka z povinného vojenského výcviku. Takovýto okamžik je v jednom dopise Tučapským rozpracován i s běžně opomíjeným (a nepředstavitelným) duševním očistcem pro skladatelovu mysl.

Další zajímavou kapitolou v tomto směru je také například Tučapského několikeré stěhování v padesátých letech, se kterým se neodmyslitelně pojí hledání možností cvičení na klavír a komponování. Tak se v dopise Tučapského Zouharovi ze 17. ledna 1954 můžeme dočíst: „Jak jsi spokojen se svým zaměstnáním? Já jsem nespokojen. Vlastně ta moje nespokojenost neni ani tak v zaměstnáni, jako spišs v těch poměrech životnich a existenčnich. Vždyt' já vlastně ani ještě nebydlím - právě, že se mám kde vyspat, ale abych komponoval - to už je slabši - a co je nejuětši tragedie, že nemám klavír a ani si nemám kde brnknout. V divadle jsou klaviry stále obsazeny a stejně musí být zvláštni povoleni $k$ uživáni, takže když to spočítám, tož týdně asi tak půl hodiny jsem u klaviru (doslova!!!) Nicméně se tomu nepoddávám, nebot' vím, že komponovat budu!! Upravoval jsem lidové pisně pro různá obsazení a jednu pro symf. orchestr to jen tak, abych nezapomnèl psát noty. "4

Tyto úryvky téměř detailně dokládají vznik různých juvenilií a dalších drobných skladeb. Následná touha po realizaci zase dává za vznik mnohým domluvám k provedení, se kterým se pojí časté úpravy a vzájemné skladatelské rady mezi oběma spolužáky.

Obtížnou situaci finanční stránky i dnešní nepředstavitelné životní podmínky (například absence ústředního topení) jsou nastíněny ve stejném dopise: „Večery trávím v diva-

4 Citace z dopisu A. Tučapského Z. Zouharovi z 17. 1. 1954. Pozůstalost Z. Zouhara, Archiv Víta Zouhara, bez signatury. 
dle, protože tam je teplo a nic mne to nestoji; v restauraci je také teplo, ale tam bych si musel dát aspoň čaj za 1,50 Kčs. "5

Rozhodnutí o hledání nového zaměstnání v tomto případě trvalo tři měsíce. Z března stejného roku totiž Tučapský Zouharovi napsal dosti zoufalým tónem: „Volám SOS jako tonouci na širém oceánu a chytám se kdejakého stébla $k$ záchraně. Už jsem se rozhodl, že musím svoji nesnesitelnou situaci napravit. V neděli jsem byl doma - v sobotu jsem měl chvilku času v Brně, tož jsem šel za Tebou, cestou jsem potkal Jardu Hrbáčka, který dospěl ke stejnému názoru jako já a jde raději učit. Nabidl mi, že bych se mohl dostat do Brna do sboru, tož jsem hned $v$ ponděli napsal Rubinkovi, tož čekám odpověd’. Ale i kdybych se dostal do Brna, byl bych zase jen sborák, tož by to byl krok z bláta do louže. Potom jsem uvažoval dál a rozhodl jsem se, že bude nejlep̌̌í, když půjdu rovnou učit. I když se dostanu na měštanku někam na dédinku, přece se dř́v dostanu ke klavíru než tady v Bratislavě. A že budu bokem kulturního ruchu? - Zrovna jako v Bratislavě, protože se dozvídám o kulturních událostech z Literárních novin. Když jsem byl v nedèli doma, chvilku jsem komponoval - nic z toho nebylo, ale aspoň jsem se ubezpečil, že přece jen komponovat budu, jen když budu mit ty nejzákladnějši životni podminky splněny, t.j. když se najim, budu bydlet a budu mít klavir. A k práci člověk nepotřebuje ruch, ale naopak klid. - Vzpominám si, žes mi před nedávnem psal o muzikantech na pedagogických školách v brněnském kraji. Prosím Tě, Ty o tom máš lep̌̌i prehled, jestli snad víš, že by snad byla naděje na některé - třeba ve Znojmě, napiš mi co nejdř́v, v kladném případě bych si zajel do Brna na KNV ohledně toho. Budu čekat Tvoji odpověd' do 15. t. m., po tomto datu bych psal na ostravský nebo gottwaldovský kraj. Skřivan mě zve do Ostravy do pionýrského domu; prý tam hledaji muzikanta, ale o to nemám zájem - to je zaměstnáni od rána do večera. Tak ještě ráz Tě prosím, abys mi ohledně toho co nejdřív napsal. Čím dřív odtud zmizim, tím lépe pro mne, protože to sboráctví by ze mne brzy udělalo duševního kreténa. " ${ }^{6}$ Bohužel zoufalá situace nedošla k rychlému řešení, Tučapský se rozhodl zůstat v Bratislavě, protože v novinách objevil inzerát na pracovní pozici asistenta hudebních nauk. ${ }^{7}$

\section{Dva světy}

Nejzásadnější změnou v životě Tučapského je bezesporu emigrace. Na první pohled by se mohlo zdát, že jediným popudem bylo zapovězené manželství s Beryl Musgrave, zpěvačkou a pedagožkou anglického původu. Tento sňatek ale především spustil lavinu událostí spojených s nelibostí vyšších autorit k západnímu světu, která se koncentrovaně sesula na osobnost Tučapského, přestože se do té doby politicky neprotivil. Pod nátlakem KV KSČ musel opustit své místo na Pedagogickém ústavu v Ostravě a místo dirigenta Pěveckého sdružení Moravských učitelů (PSMU). Následně mu bylo zapovězeno nastoupit

5 Tamtéž.

6 Citace z dopisu A. Tučapského Z. Zouharovi z 4. 3. 1954. Pozůstalost Z. Zouhara, Archiv Víta Zouhara, bez signatury.

7 „Objevil jsem inzerát v novinách, že filosofická fakulta v Bratislavě prijme asistenta hudebních nauk - intonace, harmonie, kontrapunkt, formy, instrumentace; tak se tam prihlásím; uvidime, jak to dopadne." Tamtéž. 
na jakékoli místo ve školství a kultuře, takže na dva roky nastoupil jako pomocný skladník, z čehož jeden rok byl nucen z nouze bydlet v maringotce. Po absurdních byrokratických komplikacích s přestěhováním manželů Tučapských z Československa do Velké Británie následuje pět krušných letech živoření, dluhů a začátků v cizí zemi. V korespondenci se tak poprvé objevují informace o Trinity College of Music v Londýně, na kterou byl přijat pro výuku kompozice. V tomto období (od roku 1975 do Sametové revoluce v roce 1989) nalézáme zajímavé úvahy o politickém vlivu střetů Západu s Východem na kulturní život, z čehož je nejzajímavější vlákno týkající se nápadu Zouhara na setkání s manželi Tučapskými. Takovéto setkání se povedlo na začátku 80. let dvakrát za účelem rekreace ${ }^{8}$ a jednou se podařilo domluvit koncert z díla Zouhara i Tučapského, ${ }^{9}$ na kterém vystoupila Beryl. Zouharovy pozdější tendence a nápady, že by Tučapský vedl, byt' jen jeden semestr, seminář na Janáčkově akademii múzických umění v Brně, ${ }^{10}$ se nesetkaly s úspěchem. Tlaky „shora“ zabránily i všem dalším nápadům, například pozvání Tučapského k veřejné přednášce na JAMU. S návštěvou související nápad rekreace rodiny Zouharových v Anglii se setkal s typickým odporem jakýchkoli cest z Východního bloku na Západ. Projevem byla zatížená byrokracie s dlouhými čekacími lhůtami, výběrem vhodných „spolehlivých“ kandidátů a se zamítnutým povolením. ${ }^{11}$

\section{Proti historické amnézii}

Jak naznačují výše uvedené postřehy, komunistický režim usiloval o vymazání určitých jmen z historické paměti. ${ }^{12}$ Právě manipulace kolektivní paměti patří k největším nebezpečím naší kultury. Čelíme jí vzpomínkami, psaním pamětí, památníky, zakládáním pamětových institucí. Co lze změnit v institucionalizované kolektivní paměti, ovšem nelze změnit v individuální paměti. Milan Kundera v eseji Oubli de Schoenberg ${ }^{13}$ upozorňuje na to, že bychom neměli podporovat nesmrtelnost zrůd nacistického režimu tím, že si budeme připomínat jejich hrůzné činy, ale spíše pečovat o nesmrtelnost umělců, kteří jim čelili a kteří si ji skutečně zasloužili svou odvahou a originálním tvưrčím myšlením.

Bohuslav Martinů, Jan Novák nebo Antonín Tučapský byli lidé života. Nenechávali se rozptylovat historickými a politickými okolnostmi a soustředili se na své dílo. Proto dnes píšeme dějiny těchto skladatelů, pátráme v rodinných i veřejných archivech či vzpomín-

8 Domluva v dopise Z. Zouhara A. Tučapskému ze 16. 6. 1981. Pozůstalost Z. Zouhara, Archiv Víta Zouhara, bez signatury.

9 Domluva v dopisech Z. Zouhara A. Tučapskému ze 6. 11. 1983 a 10. 3. 1984. Pozůstalost Z. Zouhara, Archiv Víta Zouhara, bez signatury.

10 V dopise Z. Zouhara A. Tučapskému z 23. 12. 1984. Pozůstalost Z. Zouhara, Archiv Víta Zouhara, bez signatury.

11 V dopise Z. Zouhara A. Tučapskému z 11. 2. 1979. Pozůstalost Z. Zouhara, Archiv Víta Zouhara, bez signatury.

12 Srov. MARTÍNKOVÁ, Alena, ed. Češti skladatelé současnosti. Praha: Panton, 1985, kde hesla "Jan Novák“ a „Antonín Tučapský“ zcela chybějí.

13 In KUNDERA, Milan. Une rencontre. Paris: Éditions Gallimard, 2009. 
kách přátel, abychom je zachytili co nejvěrněji a vrátili je zpět do kolektivní paměti, z níž měli být násilně vymazáni.

Studie vznikla na základě projektu specifického výzkumu MUNI/A/1281/2020 Skladatelé Jan Novák a Antonín Tučapský v kontextu moravské exilové hudebni kultury.

\section{Bibliography}

FRANKOVÁ, Jana. Mýtus české hudebni emigrace z pohledu Dlabačova slovniku. Musicologica Brunensia. 2015 , roč. 50 , č. 1 , s. [73]-85.

HARTL, Karla. Kauza Kaprálová. Praha: Nakladatelství Klíč, 2021.

KUNDERA, Milan. Les testaments trahis. Paris: Gallimard, 1993. [Český překlad: Improvizace na počest Stravinského. Host 2006, č. 3, s. 22, s. 14-23.]

KUNDERA, Milan. Une rencontre. Paris: Éditions Gallimard, 2009.

MARTINŮ, Bohuslav. Milý přiteli: dopisy Bohuslava Martinů Zdeňku Zouharovi / Dear friend: Bohuslav Martinư's letters to Zdeněk Zouhar. Olomouc: Univerzita Palackého v Olomouci, 2008.

MARTINŮ, Bohuslav, ZOUHAR, Vít a Gabriela COUFALOVÁ (eds.). Milý príteli Bureši: dopisy Bohuslava Martinů Miloslavu Burešovi / Dear friend Bureš: Bohuslav Martinů 's letters to Miloslav Bureš. Olomouc: Univerzita Palackého v Olomouci, 2017.

MARTINŮ, Bohuslav, ZOUHAR, Vít a Gabriela COUFALOVÁ (eds.). Milý Miloši: dopisy Bohuslava Martinu Miloši Šafránkovi. Olomouc: Univerzita Palackého v Olomouci, 2019.

MARTÍNKOVÁ, Alena, ed. Češti skladatelé současnosti. Praha: Panton, 1985.

MIHULE, Jaroslav. Martinů: Osud skladatele. Praha: Nakladatelství Karolinum, 2002, s. 432.

NĚMCOVÁ, Pavlína. Korespondence mezi Zdeňkem Zouharem a rodinou Martinů v Poličce. Brno: Masarykova univerzita, 2018. Diplomová práce. Vedoucí práce PhDr. Martin Flašar, Ph.D.

SYCHRA, Antonín. Bohuslav Martinů: Polní mše. Rytmus 11/1947-48, s. 123. 
